\title{
Specific Adverse Effects of Bevacizumab in the Treatment of Non- Squamous Non-Small Cell Lung Cancer (NSCLC) in Clinical Practice
}

\author{
LAURA MAZILU' ${ }^{1}$, DANA LUCIA STANCULEANU², ANDREEA DANIELA GHEORGHE ${ }^{1}$, ADRIAN PAUL SUCEVEANU \\ RAZVAN HAINAROSIE², IRINEL RALUCA PAREPA ${ }^{1}$, OVIDIU BRATU², CAMELIA CRISTINA DIACONU², DANIELA MANUC ${ }^{2}$, \\ ANCA PANTEA STOIAN²*, ANDRA IULIA SUCEVEANU ${ }^{1}$ \\ ${ }^{1}$ Ovidius University, Faculty of Medicine, Universitatii Str., 900470, Constanta, Romania \\ ${ }^{2}$ Carol Davila University of Medicine and Pharmacy, 8 Eroii Sanitari Str.,050474, Bucharest, Romania
}

\begin{abstract}
Lung cancer is the mostcommon cause of cancer-related mortality, and non-small cell lung cancer (NSCLC) represents about $85 \%$ of all lung cancers. In the last years, novel targeted therapies have been developed and approved in the treatment of NSCLC. Angiogenesis is a very complex process, and cancer angiogenesis is the most important event concerning cancer growth, invasion and metastasis. VEGF signalling pathway plays a significant role in cancer angiogenesis, and it is demonstrated that VEGF levels are correlated with increased angiogenesis and with poor prognosis and metastasis in NSCLC patients. Bevacizumab is a recombinant humanised monoclonal lgG1 antibody, it is one of the first agent used for anti-angiogenic treatment, and it was approved for the treatment of non-squamous NSCLC in combination with chemotherapy.
\end{abstract}

Keywords: lung cancer, bevacizumab, chemotherapy.

Lung cancer is the most common cause of cancerrelated mortality, and non-small cell lung cancer (NSCLC) represents about $85 \%$ of all lung cancers. Many patients with NSCLC are diagnosed with advanced stage disease, with a poor prognosis and a median survival of 10-12 months.

In the last years novel, targeted therapies have been developed and approved in the treatment of NSCLC.

Angiogenesis is a very complex process, it is responsible for the formation of new blood vessels from pre-existing vessels, and is a necessary process for proliferation and growth of healthy cells during the fetal period, but also for proliferation and growth of cancer cells. Cancer angiogenesis is the most important eventregarding cancer growth, invasion and metastasis[1]. In adults, angiogenesis has a limited role in wound healing and female reproductive cycle. Multiple factors are involved in the regulation of angiogenesis, but one of the most important is vascular endothelial growth factor (VEGF). VEGF levels are increased in different malignant tumours such as NSCLC, colorectal cancer, ovarian cancer and so on [2].

VEGF signalling pathway plays a significant role in cancer angiogenesis, and it consists of multiple members: VEGF-A (generally called VEGF), VEGF-B, VEGF-C, VEGF-D, and placental VEGF (PIGF), each with an essential role in angiogenesis process, and three VEGF tyrosine-kinase receptors - VEGFR-1, VEGFR-2 and VEGFR-3.VEGFR is expressed on endothelial cells and also on cancer cells[35].

It is demonstrated that VEGF levels are correlated with increased angiogenesis and with poor prognosis and metastasis in NSCLC patients, and furthermore that the levels of VEGF are higher in the patient with an advanced stage than in those with early stages [6].

Bevacizumab is a recombinant humanised monoclonal IgGl antibody, it one of the first agent used for antiangiogenic treatment, and it was approved by the US Food and Drug Administration (FDA) in 2004 for metastatic colorectal cancer, and in 2006 for the treatment of nonsquamous NSCLC in combination with chemotherapy $[7,8]$.
As mentioned before, bevacizumab is a recombinant monoclonal antibody that inhibits the activity of VEGF and its isomers, it is derived from murine anti-human VEGF, and it is $93 \%$ human and $7 \%$ murine [9].

Bevacizumab is usually well tolerated and presents an anti-VEGF toxicity profile with most common adverse events (AEs) being hypertension, bleeding and proteinuria. The studies conducted over the years have shown that bevacizumab toxicity may vary with tumour types and with patients' characteristics [10-12].

\section{Experimental part}

Materials and methods

We conducted an observational study and reviewed 68 patients with recurrent, advanced or metastatic (IIIB or IV) non-squamous NSCLC, from J anuary 2015 to June 2018, that received chemotherapy \pm bevacizumab.

Patients had histological confirmation of recurrent or advanced (IIIB or IV) non-squamous NSCLC, an ECOG performance status of $0-2$ according to Eastern Cooperative Oncology Group (ECOG), and adequate baseline haematological, hepatic and renal function.

Patients received paclitaxel and carboplatin, or paclitaxel and carboplatin plus bevacizumab. Chemotherapy was administered every 3 weeks up to six cycles, and bevacizumab $(15 \mathrm{mg} / \mathrm{kg})$ was administered every 3 weeks until disease progression, significant toxicity or patient's refusal to continue the treatment.

Patients did not receive bevacizumab if they had significant hemoptysis, history of hemorrhagic or thrombotic disorders, anticoagulation, uncontrolled hypertension and tumour invading major blood vessels.

The progression was defined according to Response Evaluation Criteria in Solid Tumors version 1.1 (RECIST 1.1), and the severity of adverse events was evaluated using Common Terminology Criteria for Adverse Events (CTCAE) version 4.0.

\section{Results and discussions}

The total group of patients in our study comprised of 68 patients with recurrent or advanced non-squamous NSCLC. 


\begin{tabular}{|c|c|c|}
\hline Characteristics & Group $A(n=32)$ & Group B $(n=36)$ \\
\hline Age (years) & & \\
\hline Median & 54 & 56 \\
\hline Range & $42-76$ & $40-78$ \\
\hline Sex & & \\
\hline Female & $11(34.37 \%)$ & $13(36.11 \%)$ \\
\hline Male & $21(65.62 \%)$ & $23(63.88 \%)$ \\
\hline Histopathologic type & & \\
\hline Adenocarcinoma & $28(87.5 \%)$ & $33(91.66 \%)$ \\
\hline Other & $4(12.5 \%)$ & $3(8.33 \%)$ \\
\hline Stage of the disease & & \\
\hline $\mathrm{IIIB}$ & $2(6.25 \%)$ & $3(8.33 \%)$ \\
\hline IV & $30(93.75 \%)$ & $33(91.66)$ \\
\hline Site of metastasis & & \\
\hline Bone & $11(34.37 \%)$ & $13(36.11 \%)$ \\
\hline Pleura & $5(15.62 \%)$ & $5(13.88 \%)$ \\
\hline Brain & $2(6.25 \%)$ & $2(5.55 \%)$ \\
\hline Adrenal glands & $8(25.0 \%)$ & $10(27.77 \%)$ \\
\hline Lung & $13(40.62 \%)$ & $15(41.66 \%)$ \\
\hline Liver & $4(12.5 \%)$ & $7(19.44 \%)$ \\
\hline Surgery & & \\
\hline Yes & $3(9.37 \%)$ & $2(5.55 \%)$ \\
\hline No & $29(90.62 \%)$ & $34(94.44 \%)$ \\
\hline Radiotherapy & & \\
\hline Yes & $7(21.87 \%)$ & $6(16.66 \%)$ \\
\hline No & $25(78.12 \%)$ & $25(83.33 \%)$ \\
\hline ECOG(performance status) & & \\
\hline 0 & $14(43.75 \%)$ & $15(41.66 \%)$ \\
\hline 1 & $10(31.25 \%)$ & $13(36.11 \%)$ \\
\hline 2 & $8(25.0 \%)$ & $8(22.22 \%)$ \\
\hline
\end{tabular}

Table 1

CLINICAL CHARACTERISTICS OF PATIENTS
Our patients were divided into two groups: Group A patients that received chemotherapy plus bevacizumab, and Group B -patients that received chemotherapy alone.

Patient characteristics are described in table 1 .

Among patients included into the study, 44 were male, and 24 were female patients, age was between 40 and 78 years, with a median age of 54 years for group $A$, and 56 years for group $B$.

Most of the cases were adenocarcinomas, and the most common metastatic sites were lung, bone and adrenal glands.

In both groups, patients received a median number of 4 cycles of chemotherapy, and in group $A$ the median number of bevacizumab cycles were 8 cycles, ranging from 1 to 16 cycles.

Adverse events related to chemotherapy that were observed in the two groups are described in table 2, and there were no significant differences between the two

Table 2

CHEMOTHERAPY RELATED ADVERSE EVENTS

\begin{tabular}{|c|c|c|}
\hline Adverse Event & $\begin{array}{l}\text { Group } A \\
n=32\end{array}$ & $\begin{array}{l}\text { Group B } \\
\mathbf{n}=36\end{array}$ \\
\hline Neutropenia & & \\
\hline Grade 2 & $9(28.12 \%)$ & $14(38.88 \%)$ \\
\hline Grade 3 & $4(12.5 \%)$ & $8(22.22 \%)$ \\
\hline Grade 4 & $2(6.25 \%)$ & $5(13.88 \%)$ \\
\hline Thrombocytopenia & & \\
\hline Grade 2 & $7(21.87 \%)$ & $8(22.22 \%)$ \\
\hline Grade 3 & $3(9.37 \%)$ & $5(13.88 \%)$ \\
\hline Grade 4 & $1(3.12 \%)$ & $2(5.55 \%)$ \\
\hline $\begin{array}{l}\text { Anemia } \\
\text { Grade } 2\end{array}$ & $4(12.5 \%)$ & $11(30.55 \%)$ \\
\hline $\begin{array}{l}\text { Anorexia } \\
\text { Grade } 2\end{array}$ & $15(46.87 \%)$ & $17(47.22 \%)$ \\
\hline Asthenia & & \\
\hline Grade 2 & $18(56.25 \%)$ & $21(58.33 \%)$ \\
\hline Vomiting & & \\
\hline Grade 2 & $4(12.5 \%)$ & $7(19.44 \%)$ \\
\hline Peripheral neuropathy & & \\
\hline Grade 1 & $21(65.62 \%)$ & $23(63.88 \%)$ \\
\hline Grade 2 & $6(18.75 \%)$ & $6(16.66 \%)$ \\
\hline Grade 3 & $1(3.12 \%)$ & 0 \\
\hline
\end{tabular}

REV.CHIM.(Bucharest) 69 No. $12 \downarrow 2018$ groups regarding common adverse events to chemotherapy.

The adverse effects associated with bevacizumab are described in table 3 . The most frequent adverse events were hypertension, proteinuria and bleeding. Most common of the adverse events were grade 1 or 2, only a few adverse

Table 3

BEVACIZUMAB RELATED ADVERSE EVENTS

\begin{tabular}{|l|l|}
\hline Adverse Event & Group $\mathbf{A}(\mathbf{n}=\mathbf{3 2})$ \\
\hline Hypertension & $6(18.75 \%)$ \\
\hline Hemoptysis & $2(6.25 \%)$ \\
\hline Epistaxis & $3(9.37 \%)$ \\
\hline Proteinuria & $11(34.37 \%)$ \\
\hline Upper digestive bleeding & $1(3.12 \%)$ \\
\hline Arterial thromboembolic events & $3(9.37 \%)$ \\
\hline Atrial fibrillation & $1(3.12 \%)$ \\
\hline Hypotension & $1(3.12 \%)$ \\
\hline Headache & $1(3.12)$ \\
\hline
\end{tabular}

events were grade 3 or 4 and lead to discontinuation of bevacizumab treatment.

Bleeding adverse events were in most cases epistaxis, 2 patients had hemoptysis, and 1 patienthad upper digestive haemorrhage due to duodenal ulcer.

Hypertension was observed in 6 patients, it was grade 2 CTCAE, and was resolved with antihypertensive medication.

Arterial thromboembolic events were observed in 3 patients, 2 patients had pulmonary thromboembolism, and one patient, a 72 years old man with stage IV NSCLC and history of arterial hypertension, experienced central nervous system ischemic event that occurs after the first administration of bevacizumab. In all three cases, the administration of bevacizumab was discontinued. 
Another patient, a 69 years old female patient, with a history of arterial hypertension and cardiac ischemic disease, had an episode of atrial fibrillation after 7 cycles of bevacizumab. The adverse event was resolved, but the patient was discontinued after receiving another 2 cycles, due to disease progression.

Hypotension was seen in one patient with stage IV NSCLC receiving bevacizumab.

Proteinuria was observed in 11 patients, and was grade 1 according to CTCAE 4.0, and did not require any dose modification in our study.

\section{Results and discussions}

The VEGF pathways have been targeted as a therapeutic option in patients with NSCLC, and Bevacizumab is an antiangiogenic drug that was approved in the treatment of NSCLC. Bevacizumab shows a benefit in overall survival of the patients with NSCLC in association with chemotherapy $[8,13]$.

Severe proteinuria can cause significant morbidity and may limit the use of bevacizumab. It is recommended to temporarily stop the treatment in case of proteinuria more than $2 \mathrm{~g} / 24$ hours and to discontinue the treatment in case of nephrotic syndrome. The incidence of severe proteinuria is different among studies [13-16]. Proteinuria was the most common side effect associated with bevacizumab treatment in our patients. 11 patients had grade 1 proteinuria and did not require any changes or delays in treatment administration.

Bleeding events like hemoptysis or pulmonary haemorrhage are common adverse events associated with bevacizumab and may lead to fatal outcome. Tumour cavitation was associated with an increased risk for bleeding in some studies, and other studies show an increased risk associated with central tumour location, squamous histology and invasion of major blood vessels [13,17-21]. In our study, 2 patients presented hemoptysis, in one patient hemoptysis was grade 1 , and in another patient grade 2, and required administration of hemostatic therapy. Epistaxis was observed in 3 patients, but the bleeding was mild and did not require any medical intervention.

Gastrointestinal bleeding was observed more frequently in patients with colorectal cancer treated with bevacizumab, but the severe bleeding was also described in clinical trials, in sites not involved with primarily cancer $[13,21]$. In our study, one patient developed upper digestive bleeding after 16 cycles of bevacizumab, and in this case, endoscopy showed a duodenal ulcer. A patient was diagnosed with stage IV adenocarcinoma, with lung metastasis, obtained a complete response after 3 cycles of chemotherapy and bevacizumab, and remained in complete response until now. [22] Bevacizumab was discontinued due to the risk of severe bleeding.

Regarding arterial thrombotic events (ATES) related to bevacizumab treatment, the risk of developing arterial thrombotic events is higher in this patients, and metaanalyses data confirm that the risk is 2-3 times higher. One meta-analysis showed an incidence of ATEs of $3.8 \%$ in patients treated with bevacizumab versus $1.7 \%$ in patients that did not receive anti-VEGF therapy, and an incidence of fatal ATEs of $0.6 \%$ within 30 days in these patients [23,24].In our study, 2 patients had ATEs (arterial pulmonary thromboembolism), and both patients were asymptomatic.

Cerebrovascular events are serious adverse events and may increase mortality in patients with cancer, and even if they are notso common, they are life-threatening. In clinical trials, the risk of ischemic stroke was not significantly different from the risk of control patients' groups [25,26].In this study, one patientexperienced central nervous system ischemic event that occurs after the first administration of chemotherapy plus bevacizumab and leads to discontinuation of treatment.

Many clinical trials have demonstrated that bevacizumab can cause an increase in blood pressure, with $30-80 \%$ of the patients developing arterial hypertension, but severe and life-threatening hypertension was observed in only $1 \%$ of these patients [27]. It is important that all patients receiving bevacizumab to be carefully evaluated and blood pressure should be monitored. Studies showed that age $>60$ years, preexisting hypertension and body mass index (BMI) $>25 \mathrm{~kg} / \mathrm{m}^{2}$ is a predictor of hypertensive response [28-30]. Our study showed a low incidence if arterial hypertension, in only 6 patients, and all these patients were previously known with arterial hypertension, and 2 of these patients were obese with a $\mathrm{BMI}>25 \mathrm{~kg} / \mathrm{m}^{2}$. All these events were managed with antihypertensive therapy and did not require any changes in patient's treatment.

One patient, a 69 years old female had one episode of paroxysmal atrial fibrillation, and the event was managed with anti-arrhythmic therapy. The patient was discontinued after 8 cycles of bevacizumab due to disease progression and not due to this cardiac event.

Although, hypertension is one of the most common adverse events in patients treated with anti-VEGF therapy, in our study one patient experience temporary hypotension after administration of bevacizumab.[31] The patient had no history of any cardiac disease and no antihypertensive medication. Some studies reported a 30\% incidence of hypotension in patients with advanced colorectal cancer treated with bevacizumab [32,33].

Neutropenia was not associated with bevacizumab treatment, but it was reported in clinical trials with a high incidence in patients receiving bevacizumab combined with chemotherapy; in our study, 2 patients from group A had grade 4 febrile neutropenia, and these 2 patients experienced this adverse event while receiving chemotherapy in association with bevacizumab [34].

\section{Conclusions}

In our study Bevacizumab was well tolerated and presented a typical anti-VEGF toxicity profile with the most common adverse events (AEs) being hypertension, proteinuria and bleeding events [35, 36]. In our group of patients, we've also experienced one cerebrovascular event and one severe episode of paroxysmal atrial fibrillation.

These clinical observations may help the physician in weighing up the risk and the benefits of bevacizumab treatment in patients with advanced or metastatic nonsmall cell lung cancer.

\section{References}

1.FOLKMAN, J., N Engl J Med.; 285(21), 1971 Nov 18,p.1182-6.

2.HANAHAN, D., WEINBERG, R.A., Cell., 144, 2011,p.646-674.

3.KAJDANIUK, D., MAREK, B., FOLTYN, W., KOS-KUDfA,

B., Endokrynol Pol.,62,2011,p.444-455.

4.KAJDANIUK, D., MAREK, B., FOLTYN, W., KOS-KUDfA, B., Endokrynol Pol.,62,2011,p.456-464.

5.TAKAHASHI, S., Biol. Pharm. Bull.,34,2011,p.1785-1788.

6.CHEN, Z.J., LE, H.B., ZHANG, Y.K., QIAN, L.Y., LI, W.D., J Int Med Res.,37(2), 2009,p.551-556.

7.HURWITZ, H., FEHRENBACHER, L., NOVOTNY, W., et al., N Engl J Med.,350(23),2004,p.2335-2342.

8.SANDLER, A., GRAY, R., PERRY, M.C., et al. N Engl J Med.,355(24), 2006,p.2542-2550.

9.KRÄMER, I., LIPP, H.P., J Clin Pharm Ther.,32, 2007,p.1-14. 
10.AN, M.M., ZOU, Z., SHEN, H., et al., Eur J Clin Pharmacol.,66, (8), 2010,p.813-821.

11.RANPURA, V., PULIPATI, B., CHU, D., ZHU, X., WU, S., Am J Hypertens.,23(5), 2010,p.460-468.

12.HANG, X.F., XU, W.S., WANG, J.X., et al., Eur J Clin Pharmacol.,67, (6), 2011,p.613-623.

13.J OHNSON, D.H., FEHRENBACHER, L., NOVOTNY, W.F., et al., J Clin Oncol., 22(11),2004,p.2184-2191.

14.GENENTECH: Avastin (bevacizumab) [Product insert], South San Francisco, Genentech, 2009.

15.ZHU, X., WU S., DAHUT, W.L., PARIKH, C.R., Am J Kidney Dis.,49,2007,p. 186-193.

16.SHENHONGWU, C.K., LEA, B., XIAOLEI, Z., J Am Soc Nephrol.,21(8), 2010,p. 1381-1389.

17.SANDLER, A., SCHILLER, J., GRAY, R., et al.,J Clin Oncol., 27,2009,p. 1405-12.

18.RECK, M., BARLES, I F., CRINO, L., et al., Ann Oncol., 23,2012, p.1111-20.

19.GOTO, K., ENDO, M., KUSUMOTO, M., YAMAMOTO, N., OHE, Y., SHIMIZU A., ANDFUKUOKA, M., Cancer Sci.,107(12), 2016,p. 18371842.

20.STANCIU, .E., ANTON, A.Z.C., STANCIU, M.M., POPESCU, C.R., GHEORGHE, D.C., NITIPIR, C., Romanian Biotechnological Letters, 2,2017,p.12419-12426

21.SANDLER, A., GRAY, R., PERRY, M.C., BRAHMER, J ., SCHILLER, J.H., DOWLATI, A., LILENBAUM, R., JOHNSON, D.H., N Engl J Med.,355(24), 2006,p.2542-2550.

22.GIURCANEANU, C., NITIPIR, C., POPA, L.G., FORSEA, A.M., POPESCU, I., BUMBACEA, R.S., Acta Dermatovenerologica Croatica, 23, 2,2015,p. 114-121

23.ABDEL-QADIR, H., ETHIER, J.L., LEE, D.S., THAVENDIRANATHAN, P., AMIR, E., Cancer Treat Rev.53, 2017, p.120-127.
24.SCAPPATICCI, F.A., SKILLINGS, J.R., HOLDEN, S.N., GERBER, .H.P., MILLER, K., KABBINAVAR, F., J Natl Cancer Inst,,99, 2007,p.1232-1239. 25.RANPURA, V., HAPANI, S., CHUANG, J., WU, S. Acta Oncol., 49, 2010,p. 287-297.

26.PEI-YUAN, Z., XING-LIN, C., YU-WEI, L., CHANG-LIANG, X., CHENGYUN, L., PLoS One., 9(7), 2014,p. e102484.

27.IZZEDINE, H., EDERHY, S., GOLDWASSER, F., SORIA, J .C., MILANO, G., COHEN, A., Ann Oncol.,20, 2007,p.807-815.

28.MAITLAND, M.L., KASZA, K.E., KARRISON, T., MOSHIER, K., SIT, L., BLACK, H.R., Clin Cancer Res.,15, 2009,p.6250-6257.

29.HAMNVIK, O.P., CHOUEIRI, T.K., TURCHIN, A., MCKAY, R.R., GOYAL, L., DAVIS, M., Cancer.,121, 2015,p.311-319.

30.FODOR K., TIT D. M., PASCA B., BUSTEA C., UIVAROSAN D., ENDRES L., IOVAN C., ABDEL-DAIM M., BUNGAU S., Oxidative Medicine and Cellular Longevity, ID 4147320, 2018. https://doi.org/10.1155/2018/ 4147320

31.NITIPIR, C., BARBU, M.A., POPA, L.G., MIHAI, M.M., RADU, I. MIREA, D., GIURCANEANU, C. SCAUNASU, R.V., Farmacia, 63(6),2015,p. 805810

32.KANAI, M., ISHIGURO, H., MORI, Y., KITANO, T., NISHIMURA, T., MATSUMOTO, S., YANAGIHARA, K., CHIBA, T., TOI, M., British J ournal of Cancer, 105,2011,p. 1693-1696.

33.PALLAG A., ROSCA E., TIT D. M., MUTIU G., BUNGAU S. G., POP O. L., Romanian Journal of Morphology and Embriology, 56(3),2016, p.1103-1109

34.KOZLOFF, M., COHN, A., CHRISTIANSEN, N., et al., J Clin Oncol.,23(Suppl), 2005,16S-16S.

35.POIANA, C., NEAMTU, M. C., AVRAMESCU, E. T. et al., Romanian Journal Of Morphology And Embryology, 54(3),2013,p. 717-720.

36.NECHITA, A.M., PITURU,S., RADULESCU, D.,et al.,Farmacia, 64(3),2016,p.348-357.

Manuscript received: 22.07 .2018 